\title{
Possible Roles of Intracellular Cyclic AMP, Protein Kinase $C$ and Calcium Ion in the Apoptotic Signaling Pathway in Bovine Luteal Cells
}

\author{
Yuko TATSUKAWA ${ }^{1)}$, Anom BOWOLAKSONO ${ }^{1)}$, Ryo NISHIMURA ${ }^{1)}$, \\ Junichi KOMIYAMA ${ }^{1}$, , Tomas J. ACOSTA ${ }^{1)}$ and Kiyoshi OKUDA ${ }^{1)}$ \\ 1) Laboratory of Reproductive Endocrinology, Graduate School of Natural Science and \\ Technology, Okayama University, Okayama 700-8530, Japan
}

\begin{abstract}
Structural luteolysis occurs by apoptosis of luteal cells. The present study examined the effects of activators of well-characterized second messengers on Fas and caspase-3 mRNA expression and on $\mathrm{P} 4$ production in luteal cells in order to trace the pro- and anti-apoptotic factors in the bovine corpus luteum (CL). Cultured bovine mid luteal cells were treated for $24 \mathrm{~h}$ with a cyclic AMP analogue (8-bromo cyclic AMP; 8br-cAMP; $2.5 \mathrm{mM}$ ), a protein kinase C (PKC) activator (phorbol 12myristate 13-acetate; PMA; $10 \mu \mathrm{M})$, or calcium ionophore (A23187; $10 \mu \mathrm{M})$. Fas and caspase-3 mRNA expression was inhibited by 8br-cAMP and PMA but was increased by A23187 $(\mathrm{P}<0.05)$. In addition, P4 production by bovine luteal cells was stimulated by $8 \mathrm{br}-\mathrm{cAMP}$ and PMA, whereas it was inhibited by A23187, compared with untreated controls $(\mathrm{P}<0.05)$. The overall results suggest that cAMP and PKC suppress apoptosis in bovine luteal cells through inhibition of Fas and caspase-3 mRNA expression and through stimulation of $\mathrm{P} 4$ production. Therefore, substances that activate cAMP or PKC may act as survival factors in the bovine CL. Furthermore, substances that mobilize $\mathrm{Ca}^{2+}$ may act as apoptotic factors by stimulating Fas and caspase-3 expression in the bovine luteal cells.

Key words: Corpus luteum, Apoptosis, Anti-apoptotic factor, Second messenger, Cow
\end{abstract}

(J. Reprod. Dev. 52: 517-522, 2006)

n mammals, luteolysis occurs on two levels

corresponding to functional luteolysis and structural luteolysis [1]. Structural luteolysis occurs by luteal cell apoptosis [1], which is known to be regulated by Fas antigen (Fas) [2-4] and caspases [3-6]. Fas is a member of the tumor necrosis factor receptor superfamily, and engagement of Fas with Fas ligand (Fas L) induces apoptosis [7]. Caspases, a family of aspartic acidspecific cysteine proteases, are pivotal mediators of apoptosis during regression of the corpus luteum (CL) $[5,8]$. Caspase-3 appears to have an especially

Accepted for publication: April 10, 2006

Published online: May 8, 2006

Correspondence: K. Okuda (e-mail: kokuda@cc.okayama-u.ac.jp) important role in luteolysis [3, 5, 9]. Recently, we found that progesterone $(\mathrm{P} 4)$ protects bovine luteal cells from apoptosis by attenuating Fas mRNA expression and caspase-3 activity [3], suggesting that the CL is protected from apoptosis by $\mathrm{P} 4$.

Luteinizing hormone ( $\mathrm{LH}$ ) is known to be the major hormonal regulator of $\mathrm{P} 4$ synthesis in luteal cells. Cyclic AMP (cAMP) is considered to be a primary second messenger of $\mathrm{LH}$ action in the corpus luteum [10,11]. Two other secondary messengers involved in $\mathrm{P} 4$ production are protein kinase $C(P K C)$ and intracellular calcium ions $\left(\mathrm{Ca}^{2+}\right)$, which are required for the activation of PKC [12]. However, the effects of these factors on apoptosis signaling pathways in bovine luteal cells 
remain unknown.

The present study examined the effects of a cAMP analogue, a PKC activator and calcium ionophore on Fas and caspase-3 mRNA expression and on $\mathrm{P} 4$ production in cultured bovine luteal cells, in order to trace pro-apoptotic and antiapoptotic factors in the bovine CL.

\section{Materials and Methods}

\section{Collection of $C L$}

Ovaries with a mid-stage CL were collected from Holstein cows at a local abattoir within 10-20 min after exsanguination. Mid-stage CLs were identified by macroscopic observation of the ovary and uterus as described previously $[13,14]$. For cell culture experiments, ovaries with CL were submerged in ice-cold physiological saline and transported to the laboratory.

\section{Cell isolation}

Luteal cells were prepared by enzymatically dissociating luteal tissue and were cultured as described previously [15]. The luteal cells were suspended in a culture medium, Dulbecco's Modified Eagle's Medium and Ham's F-12 Medium (D/F medium; 1:1 [v/v], D8900; Sigma-Aldrich, Inc., St. Louis, MO, USA) containing 5\% calf serum (CS; 16170-078; Gibco BRL, Grand Island, NY, USA) and $20 \mu \mathrm{g} / \mathrm{ml}$ gentamicin (15750-060; Gibco). Cell viability was greater than $85 \%$ as assessed by trypan blue exclusion. The cells in the cell suspension consisted of about $70 \%$ small luteal cells, $20 \%$ large luteal cells, $10 \%$ endothelial cells or fibrocytes, and no erythrocytes.

\section{Cell culture and experiments}

The dispersed luteal cells were seeded at $2.0 \times 10^{5}$ viable cells in $1.0 \mathrm{ml}$, in 24-well culture dishes (3524; Costar, Cambridge, MA, USA). After 24 h of culture, the medium was replaced with $D / F$ medium containing $0.1 \%$ bovine serum albumin (BSA; A7888; Sigma), $5 \mathrm{ng} / \mathrm{ml}$ sodium selenite, and $5 \mu \mathrm{g} / \mathrm{ml}$ transferrin. The cells were then treated with $2.5 \mathrm{mM}$ 8-bromo cyclic AMP (a cyclic AMP analogue; 8br-cAMP; B7880; Sigma), $10 \mu \mathrm{M}$ A23187 (calcium ionophore; C7522; Sigma), or $10 \mu \mathrm{M}$ phorbol 12-myristate 13-acetate (a PKC activator; PMA; P8139; Sigma) for $24 \mathrm{~h}$. The conditioned media from the last $24 \mathrm{~h}$ of culture were collected and stored at $-30 \mathrm{C}$ until assayed for P4. For determination of Fas and caspase-3 mRNA expression, total RNA was prepared from the cultured luteal cells using TRIZOL Reagent (15596; Invitrogen, Carlsbad, CA, USA) according to the manufacturer's directions.

\section{Semiquantitative reverse transcription-polymerase} chain reaction ( $R T-P C R$ )

Total RNA (1 $\mu \mathrm{g})$ was reverse transcribed using a ThermoScript ${ }^{\text {TM }}$ RT-PCR System (11146-016; Invitrogen), and the reaction mixture was used in each PCR together with the appropriate oligonucleotide primer pairs. RT-PCR was carried out using the housekeeping gene $\beta$-actin as an internal standard. The sequences of the Fas primers, which were based on the report of Vickers et al. [16], were 5'-ATG GGC TAG AAG TGG AAC AAA AC-3' (5' primer, 23 mer) and 5'-CAG GAG GGC CCA TAA ACT GTT TGC-3' (3' primer, 24 mer). These primers generated a specific 206 base pair (bp) product. The primers for caspase-3 were based on the ovine caspase-3 (AF068837) sequence [5]. The primers were chosen using the Primer3 online application (http://wwwgenome.wi.mit.edu/cgi-bin/primer / primer3_www.cgi) and were as follows: caspase-3 forward 5'-AGC AAA CCT CAG GGA AAC CT-3' and reverse 5'-GGC AGG CCT GAA TAA TGA AA-3' $(278 \mathrm{bp})$. The sequences of the $\beta$-actin primers, which were designed as described by Leung et al. [17], were 5'-GAA GAT CTG GCA CCA CAC-3' (5' primer, 18 mer) and 5'-AGA GGC GTA CAG GGA CAG C-3' (3' primer, 19 mer). These primers generated a specific $200 \mathrm{bp}$ product. Caspase-3 mRNA expression was calculated using these primers. The sequences of the other $\beta$-actin primers, which were designed as described by Asselin and Fortier [18], were 5'-GAG GAT CTT CAT GAG GTA GTC TGT CAG GTC-3' (5' primer, 30 mer) and 5'-CAA CTG GGA CGA CAT GGA GAA GAT CTG GCA-3' (3' primer, 30 mer). These primers generated a specific $349 \mathrm{bp}$ product. Fas mRNA expression was calculated using these primers. The PCRs were carried out using TaKaRa Taq (R001A; Takara Bio Inc., Ohtsu, Shiga, Japan) and a thermal cycler (iCycler Thermal Cycler 170 8720; Bio-Rad, Hercules, CA, USA). The conditions for the PCRs were as follows: after activation of the DNA polymerase by incubating for $0.5 \mathrm{~min}$ at $95 \mathrm{C}$, 27 (Fas and caspase-3) and 18 ( $\beta$-actin) cycles of 

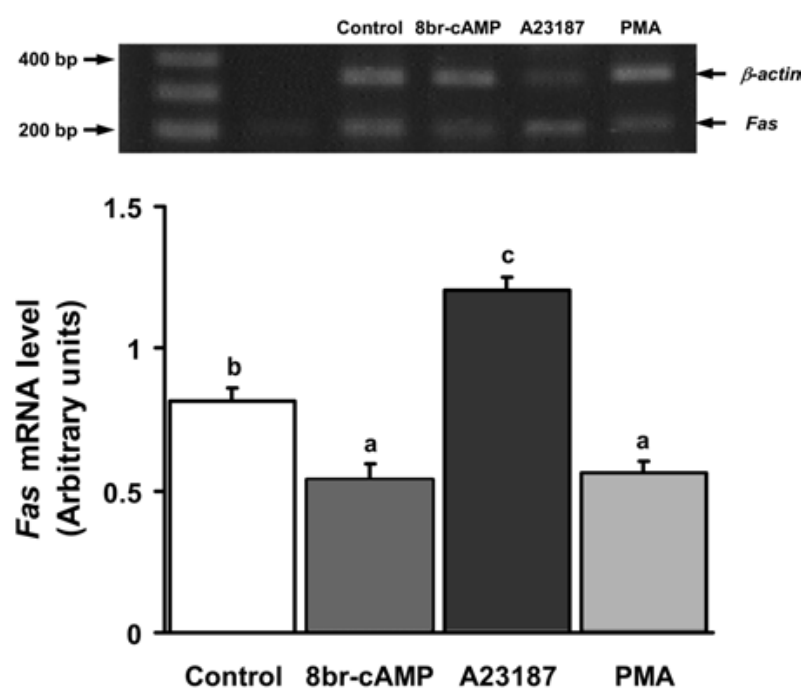

Fig. 1. Effects of 8-bromo cyclic AMP (8br-cAMP; $2.5 \mathrm{mM}$ ), phorbol 12-myristate 13-acetate (a PKC activator; PMA; $10 \mu \mathrm{M}$ ), and A23187 (calcium ionophore; $10 \mu \mathrm{M}$ ) on Fas mRNA expression in cultured bovine luteal cells $(n=4)$. The cells were treated with 8br-cAMP, A23187, or PMA in the final $24 \mathrm{~h}$ of culture. Upper panel: representative sample of specific RT-PCR products for Fas (206 bp) and $\beta$-actin (349 bp) separated by agarose gel electrophoresis. Lower panel: relative levels of Fas mRNA (RT-PCR 27 cycles, arbitrary units). All values are means \pm SEM of densitometric analysis of Fas mRNA levels in the cells (relative to $\beta$-actin mRNA levels). Different letters indicate significant differences $(\mathrm{P}<0.05)$, as determined by ANOVA followed by a Fisher's PLSD as a multiple comparison test.

reactions including denaturation for $0.5 \mathrm{~min}$ at 95 $\mathrm{C}$, annealing for $1 \mathrm{~min}$ at $60 \mathrm{C}$, and extension for 1 min at $70 \mathrm{C}$ were performed, followed by an additional extension for $5 \mathrm{~min}$ at $72 \mathrm{C}$. The PCR amplification was calibrated to determine the optimal number of cycles that would allow detection of the appropriate mRNA transcripts while still keeping amplification of these genes in the log phase. A portion (40\%) of each reaction mixture was electrophoresed on a $1.5 \%$ agarose gel with a known standard (100 bp Ladder; N3231S; New England BioLabs Inc., Beverly, MA, USA), stained with ethidium bromide, and photographed under UV illumination. The relative band intensities were analyzed by computerized densitometry using NIH Image (National Institutes of Health, Bethesda, MD, USA).
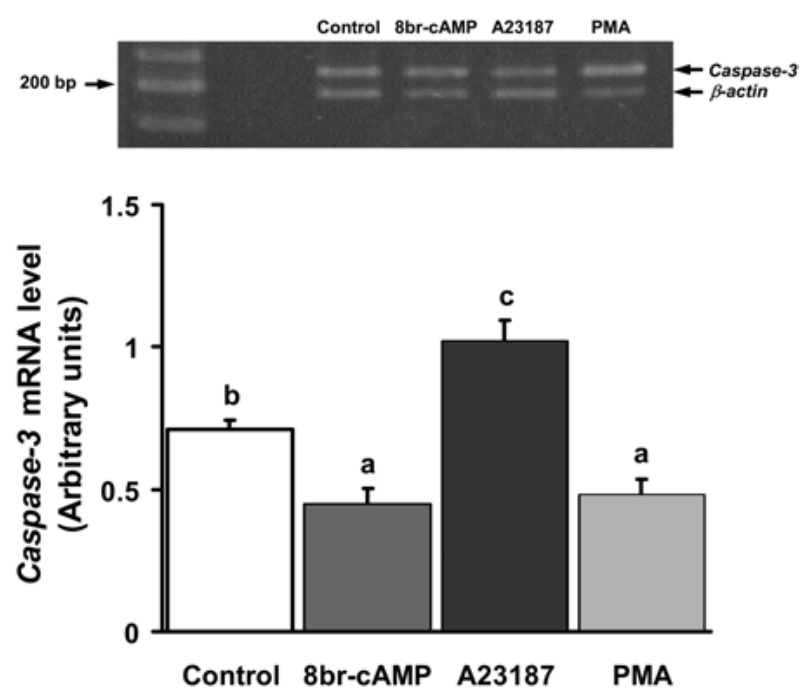

Fig. 2. Effects of 8br-cAMP (2.5 mM), PMA $(10 \mu \mathrm{M})$, and A23187 $(10 \mu \mathrm{M})$ on caspase-3 mRNA expression in cultured bovine luteal cells $(n=4)$. The cells were treated with 8br-cAMP, A23187, or PMA in the final $24 \mathrm{~h}$ of culture. Upper panel: representative sample of specific RT-PCR products for caspase-3 (278 bp) and $\beta$ actin $(200 \mathrm{bp})$ separated by agarose gel electrophoresis. Lower panel: relative levels of caspase-3 mRNA (RT-PCR 27 cycles, arbitrary units). All values are means \pm SEM of densitometric analysis of caspase-3 mRNA levels (relative to $\beta$-actin mRNA levels). Different letters indicate significant differences $(\mathrm{P}<0.05)$, as determined by ANOVA followed by a Fisher's PLSD as a multiple comparison test.

\section{P4 determination}

The concentrations of $\mathrm{P} 4$ were determined directly from the cell culture media using a previously described enzyme immunoassay [19], which was modified from its original method [20].

Briefly, progesterone 3-(O-carboxymethyl) oxime linked to peroxidase type VI through a 6aminocaproic acid spacer (P3659; Sigma) was used as a tracer (1:10,000 final dilution). Antiserum of progesterone (OK-1) was produced as follows: $11 \alpha-$ hydroxy progesterone-11-hemisuccinate-BSA (H4508; Sigma) was suspended in physiological saline $(0.25 \mathrm{ml})$, emulsified with complete Freund's adjuvant $(0.25 \mathrm{ml}$; Difco Laboratories, Detroit, MI, USA), and then injected intradermally into a female rabbit (New Zealand White) at a number of sites on her back and abdomen. After 20 injections at 2- to 4-wk intervals, blood samples were taken. Crossreactivity of the anti-progesterone serum, validated 


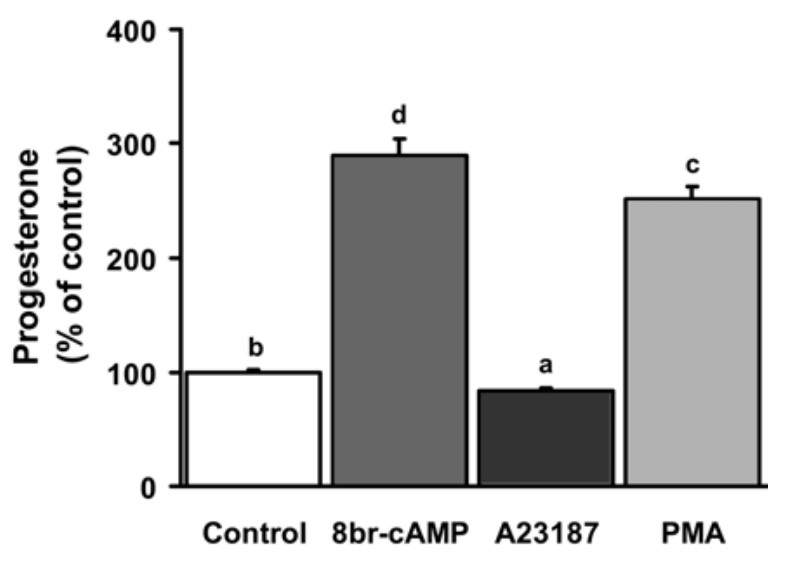

Fig. 3. Effects of 8br-cAMP (2.5 mM), PMA $(10 \mu \mathrm{M})$, and A23187 $(10 \mu \mathrm{M})$ on progesterone production in bovine luteal cells (mean \pm SEM, $n=4$ ). The cells were treated with 8br-cAMP, A23187, and PMA in the final $24 \mathrm{~h}$ of culture. All values are expressed as a percentage of the control value. The concentration of progesterone in the control was $889.89 \pm 36.6 \mathrm{ng} / \mathrm{ml}$. Different letters indicate significant differences $(\mathrm{P}<0.05)$, as determined by ANOVA followed by a Fisher's PLSD as a multiple comparison test.

by comparing the inhibition of binding of perioxydase-labeled progesterone to antiserum, were as follows: progesterone, $100 \%$; $5 \alpha$ pregnanedion, $7.1 \%$; pregnenolone, $2.4 \% ; 17 \alpha-$ hydroxyprogesterone, $1.0 \% ; \quad 20 \alpha-$ hydroxyprogesterone, $0.7 \%$; deoxycorticosterone, $1.2 \%$; corticosterone, $0.3 \%$; estradiol $-17 \beta,<0.1 \%$; testosterone, $<0.1 \%$; and androstenedione, $<0.1 \%$. The final antibody dilution was 1:100,000. The standard curve ranged from 0.391 to $100 \mathrm{ng} / \mathrm{ml}$, and the effective dose of the assay for $50 \%$ inhibition (ED50) was $4.5 \mathrm{ng} / \mathrm{ml}$. The intra- and inter-assay coefficients of variation were 9.3 and $14.5 \%$, respectively.

\section{Statistical analysis}

All experimental data are shown as the mean \pm SEM. The data on the effects of 8br-cAMP, A23187, and PMA on $\mathrm{P} 4$ production are shown as a percentage of the control. The statistical significance of differences in $\mathrm{P} 4$ concentrations and Fas and caspase- 3 mRNA expression were assessed by analysis of variance (ANOVA) followed by a Fisher's protected least-significant difference (PLSD) procedure as a multiple comparison test.

\section{Results}

Effects of 8br-cAMP, PMA, and A23187 on Fas and caspase- 3 mRNA expression

Representative samples of the Fas- and caspase-3specific RT-PCR products (206 and $278 \mathrm{bp}$ ) are shown in the upper panels of Figs. 1 and 2, respectively. The relative signal intensities for PCR products specific for Fas and caspase-3 mRNAs were assessed after correction based on the $\beta$-actin signal intensities (lower panels of Figs. 1 and 2, respectively). Both $8 \mathrm{br}-\mathrm{cAMP}$ and PMA significantly decreased Fas mRNA expression $(\mathrm{P}<0.05)$, while A23187 increased Fas mRNA expression $(\mathrm{P}<0.05)$. Similar to Fas, the mRNA expression of caspase-3 was significantly decreased by 8 br-cAMP and PMA $(\mathrm{P}<0.05)$ whereas it was increased by $\mathrm{A} 23187(\mathrm{P}<0.05)$.

\section{Effects of 8br-cAMP, PMA, and A23187 on P4 production}

$\mathrm{P} 4$ production by bovine luteal cells was stimulated by 8br-cAMP and PMA, whereas it was inhibited by A23187, compared with untreated controls ( $\mathrm{P}<0.05$; Fig. 3$)$.

\section{Discussion}

The preceding results demonstrate that wellknown second messengers (cAMP, PKC, and $\mathrm{Ca}^{2+}$ ) are related to apoptosis in bovine luteal cells through regulation of caspase-3 and Fas mRNA expression. Fas is a cell surface receptor that triggers apoptosis in sensitive cells when Fas L binds to it [7], whereas caspase- 3 is a member of the caspase family, which has pivotal roles in apoptosis in many cell types, including bovine luteal cells [3, $5,8]$. The roles of Fas and caspase- 3 in luteal regression have previously been documented in cattle $[2,5,6]$. In the present study, the findings that Fas and caspase-3 mRNA expression was suppressed by $8 \mathrm{br}$-cAMP and PMA indicate that cAMP accumulation and activation of PKC play roles in protecting bovine luteal cells from apoptosis.

CL function is regulated by various bioactive substances, such as gonadotropins, steroids, and growth factors. Among these substances, luteinizing hormone (LH) [21, 22], epidermal growth factor (EGF) [23], and prostaglandin (PG) 
E2 [24, 25] have been reported to stimulate accumulation of cAMP via activation of adenylate cyclase (AC), whereas PGF2 $\alpha$ is known to activate PKC in luteal cells $[15,26]$. Therefore, it is possible that substances that activate AC or PKC, such as LH, EGF, PGE2, and PGF2 $\alpha$ may act as survival factors and protect the bovine CL against apoptosis. Further studies are needed to clarify which substances have anti-apoptotic roles in the bovine CL.

We have recently shown that $\mathrm{P} 4$ suppresses apoptosis in bovine luteal cells through inhibition of the expression of apoptosis-related genes and by the suppression of caspase- 3 activity [3]. In the present study, 8br-cAMP and PMA stimulated P4 production, whereas they inhibited Fas and caspase3 mRNA expression in luteal cells. Thus, the suppression of caspase-3 and Fas mRNA expression by 8 br-cAMP and PMA observed in the present study might be mediated by $\mathrm{P} 4$. In support of this idea, we previously found that Fas [2] and caspase-3 mRNA expression was low in the bovine CL in the mid and late luteal stages when the CL synthesizes high amounts of P4 (unpublished data).

On the other hand, we demonstrated that inducing intracellular $\mathrm{Ca}^{2+}$ mobilization by $\mathrm{A} 23187$ suppressed $\mathrm{P} 4$ production, whereas $\mathrm{Ca}^{2+}$ increased Fas and caspase-3 mRNA expression in the luteal cells in the present study. The vasoactive peptides endothelin-1 (ET-1) and angiotensin II (Ang II) act through $\mathrm{Ca}^{2+}$ mobilization $[27,28]$. In addition, these peptides have been suggested to play important roles during physiological and PGF2 $\alpha-$ induced luteolysis concomitant with decreasing P4 production in cows [27, 29-31]. Therefore, ET-1 and Ang II might be the factors that induce apoptosis via $\mathrm{Ca}^{2+}$ mobilization in bovine luteal cells.

The overall results of the present study indicate that the intracellular signaling pathways via cAMP, PKC, or $\mathrm{Ca}^{2+}$ are related to the regulation of luteal cell apoptosis and suggest that the substances that act via CAMP or PKC protect cells from apoptosis, whereas those that act via $\mathrm{Ca}^{2+}$ induce apoptosis in bovine luteal cells.

\section{Acknowledgements}

This research was supported by a Grant-in-Aid for Scientific Research (No.18380166) from the Japan Society for the Promotion of Science (JSPS) and Grants-in-Aid for Scientific Research for Excellent Research Projects from Okayama University. R. Nishimura was supported by a JSPS Research Fellowship (No. 03589).

\section{References}

1. McCracken JA, Custer EE, Lamsa JC. Luteolysis: a neuroendocrine-mediated event. Physiol Rev 1999; 79: 263-323

2. Taniguchi H, Yokomizo Y, Okuda K. Fas-Fas ligand system mediates luteal cell death in bovine corpus luteum. Biol Reprod 2002; 66: 754-759.

3. Okuda K, Korzekwa A, Shibaya M, Murakami S, Nishimura R, Tsubouchi M, Woclawek-Potocka I, Skarzynski DJ. Progesterone is a suppressor of apoptosis in bovine luteal cells. Biol Reprod 2004; 71: 2065-2071.

4. Carambula SF, Pru JK, Lynch MP, Matikainen T, Goncalves PB, Flavell RA, Tilly JL, Rueda BR. Prostaglandin F2 $\alpha$ - and FAS-activating antibodyinduced regression of the corpus luteum involves caspase- 8 and is defective in caspase- 3 deficient mice. Reprod Biol Endocrinol 2003; 1: 15.

5. Carambula SF, Matikainen T, Lynch MP, Flavell RA, Dias Goncalves PB, Tilly JL, Rueda BR. Caspase-3 is a pivotal mediator of apoptosis during regression of the ovarian corpus luteum.
Endocrinology 2002; 143: 1495-1501.

6. Yadav VK, Lakshmi G, Medhamurthy R. Prostaglandin F2 $\alpha$-mediated activation of apoptotic signaling cascades in the corpus luteum during apoptosis: involvement of caspase-activated DNase. J Biol Chem 2005; 280: 10357-10367.

7. Nagata S, Golstein P. The Fas death receptor. Science 1995; 267: 1449-1456.

8. Pru JK, Tilly JK. Programmed cell death in the ovary: insights and future prospects using genetic technologies. Mol Endocrinol 2001, 15: 845-853.

9. Rueda BR, Hendry IR, Tilly JL, Hamernik DL. Accumulation of caspase-3 messenger ribonucleic acid and induction of caspase activity in the ovine corpus luteum following prostaglandin F2 $\alpha$ treatment in vivo. Biol Reprod 1999; 60: 1087-1092.

10. Williams MT, Clark MR, Ling WY, LeMaire WJ, Caron MG, Marsh JM. The role of cyclic AMP in the action of luteinizing hormone on steroidogenesis in the corpus luteum. Adv Cyclic Nucleotide Res 1978; 9: $573-582$. 
11. Garverick HA, Smith MF, Elmore RG, Morehouse GL, Agudo LS, Zahler WL. Changes and interrelationships among luteal LH receptors, adenylate cyclase activity and phosphodiesterase activity during the bovine estrous cycle. J Anim Sci 1985; 61: 216-223.

12. Davis JS. Mechanisms of hormone action: luteinizing hormone receptors and secondmessenger pathways. Curr Opin Obstet Gynecol 1994; 6: 254-261.

13. Okuda K, Kito S, Sumi N, Sato K. A study of the central cavity in the bovine corpus luteum. Vet Rec 1988; 123: 180-183.

14. Miyamoto Y, Skarzynski DJ, Okuda K. Is tumor necrosis factor $\alpha$ a trigger for the initiation of endometrial prostaglandin F2 $\alpha$ release at luteolysis in cattle? Biol Reprod 2000; 62: 1109-1115.

15. Okuda K, Uenoyama Y, Lee KW, Sakumoto R, Skarzynski DJ. Progesterone stimulation by prostaglandin F2 $\alpha$ involves the protein kinase C pathway in cultured bovine luteal cells. J Reprod Dev 1998; 44: 79-84.

16. Vickers SL, Cowan RG, Harman RM, Porter DA, Quirk SM. Expression and activity of the Fas antigen in bovine ovarian follicle cells. Biol Reprod 2000; 62: 54-61.

17. Leung ST, Derecka K, Mann GE, Flint AP, Wathes DC. Uterine lymphocyte distribution and interleukin expression during early pregnancy in cows. J Reprod Fertil 2000; 119: 25-33.

18. Asselin E, Fortier MA. Detection and regulation of the messenger for a putative bovine endometrial 9keto-prostaglandin E(2) reductase: effect of oxytocin and interferon- $\tau$. Biol Reprod 2000; 62: 125-131.

19. Sakumoto R, Ando Y, Okuda K. Progesterone release of bovine corpus luteum in response to oxytocin in different culture system. J Reprod Dev 1996; 42: 199-204.

20. Prakash BS, Meyer HHD, Schallenberger E, Van de Wiel DFM. Development of a sensitive enzymeimmunoassay (EIA) for progesterone determination in unextracted bovine plasma using the second antibody technique. J Steroid Biochem 1987; 28: 623-627.

21. Taniguchi H, Uenoyama Y, Miyamoto Y, Okuda K. The lipoxygenase pathways are involved in LHstimulated progesterone production in bovine corpus luteum. Prostaglandins Other Lipid Mediat 2002; 67: 49-60.

22. Nishimura R, Shibaya M, Skarzynski DJ, Okuda
K. Progesterone stimulation by LH involves the phospholipase-C pathway in bovine luteal cells. J Reprod Dev 2004; 50: 257-261.

23. Budnik LT, Mukhopadhyay AK. Epidermal growth factor, a modulator of luteal adenylate cyclase. Characterization of epidermal growth factor receptors and its interaction with adenylate cyclase system in bovine luteal cell membrane. J Biol Chem 1991; 266: 13908-13913.

24. Godkin JD, Black DL, Duby RT. Stimulation of cyclic AMP and progesterone synthesis by LH, PGE2 and isoproterenol in the bovine CL in vitro. Biol Reprod 1977; 17: 514-518.

25. Feng SM, Almond GW. Effects of LH, prostaglandin E2, 8-bromo-cyclic AMP and forskolin on progesterone secretion by pig luteal cells. J Reprod Fertil 1998; 113: 83-89.

26. Sen A, Choudhary E, Inskeep EK, Flores JA. Effects of selective protein kinase $\mathrm{C}$ isozymes in prostaglandin $\mathrm{F}_{2 \alpha}$-induced $\mathrm{Ca}^{2+}$ signaling and luteinizing hormone-induced progesterone accumulation in the mid-phase bovine corpus luteum. Biol Reprod 2005; 72: 976-984.

27. Choudhary E, Sen A, Inskeep EK, Flores JA. Developmental sensitivity of the bovine corpus luteum to prostaglandin $\mathrm{F}_{2 \alpha}\left(\mathrm{PGF}_{2 \alpha}\right)$ and endothelin1 (ET-1): is ET-1 a mediator of the luteolytic actions of $\mathrm{PGF}_{2 \alpha}$ or a tonic inhibitor of progesterone secretion? Biol Reprod 2005; 72: 633-642.

28. Pepperell JR, Nemeth G, Yamada Y, Naftolin F. The type 1 angiotensin-II receptor mediates intracellular calcium mobilization in rat luteal cells. Endocrinology 1993; 133: 1678-1684.

29. Schams D, Brisha B, Neuvians T, Amselgruber W, Kraetzl WD. Real-time changes of the local vasoactive peptide systems (angiotensin, endothelin) in the bovine corpus luteum after induced luteal regression. Mol Reprod Dev 2003; 65: 57-66.

30. Shirasuna K, Asaoka H, Acosta TJ, Wijayagunawardane MP, Ohtani M, Hayashi M, Matsui M, Miyamoto A. Real-time relationship in intraluteal release among prostaglandin $\mathrm{F} 2 \alpha$, endothelin-1, and angiotensin II during spontaneous luteolysis in the cow. Biol Reprod 2004; 71: 1706-1711.

31. Hayashi K, Miyamoto A. Angiotensin II interacts with prostaglandin F2 $\alpha$ and endothelin-1 as a local luteolytic factor in the bovine corpus luteum in vitro. Biol Reprod 1999; 60: 1104-1109. 